\title{
PRLR wt Allele
}

National Cancer Institute

\section{Source}

National Cancer Institute. PRLR wt Allele. NCI Thesaurus. Code C51719.

Human PRLR wild-type allele is located within 5p14-p13 and is approximately $182 \mathrm{~kb}$ in length. This allele, which encodes prolactin receptor protein, is involved in the regulation of receptor-mediated interactions for the anterior pituitary hormone prolactin. 